\title{
Charred Rice Hull as Soil Additive to Reduce Arsenic Uptake by Oryza sativa in a Rice Farm
}

\author{
Ruby Broadway, Agwaramgbo Lovell E*, Shelby Edwards, ShaKayla Nunez and Joy Semien \\ School of Science, Technology, Engineering, and Mathematics (STEM), Dillard University, USA \\ *Corresponding author: Dr. Lovell E Agwaramgbo,Chair School of STEM, Dillard University, Louisiana, PSB 342-G, Dillard University, Louisiana, PSB \\ 342-G, USA
}

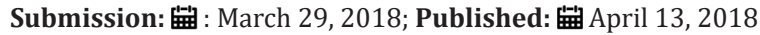

\begin{abstract}
The ecosystem (land, water, air) and the organisms that inhabit it are exposed to various heavy metals at varying levels. However, concerns arise when the potential exist for the levels of these toxicants to exceed the regulatory thresholds. Arsenic is a well-known soil and water contaminant with reported toxic and detrimental risks to the ecosystem, human health, aquatic and terrestrial animals, and plants. Intake of arsenic contaminated water and food diet form the major source of arsenic exposure to humans. Rice paddy rice (Oryza sativa), a major staple food for many countries of the world has been reported to have the capacity to accumulate a large amount of arsenic from contaminated soil or from contaminated irrigation water. The sources of these arsenic could be as a result of old agricultural practices that utilized arsenate insecticide. Chinese fern has been identified as a potential agent for the phytoremediation of arsenic contaminated soil. Additionally, biochars and charcoal have been used for the remediation of $\mathrm{Pb}, \mathrm{Cu}, \mathrm{Zn}, \mathrm{Cd}$ from contaminated water. The project reported here investigated the use of charred rice hulls for the remediation of arsenic contaminated rice farm in the North-Western part of Louisiana. Results demonstrate that rice is an accumulator of arsenic if the soil is contaminated with arsenic. Irrigation water was not a source of arsenic contamination for this project for all the irrigation water samples showed no trace of arsenic. Furthermore, the rice hull and rice straw from previous year used in the preparation of the charred biomaterial appear to be contaminated and thus, increased the soil arsenic but decreased arsenic uptake into the rice grain.
\end{abstract}

Keywords: Fertilizers; Oryza sativa; Pesticides; Phytoremediation; Herbicide

\section{Introduction}

Arsenic is one of the trace metals that occur naturally in rocks and soil but their release into the environment is exacerbated by human activities such as those by mining [1], lumber [2,3], and agrochemical (fertilizers, pesticides, fungicides, herbicides) industries [4,5]. Many studies have determined that arsenic exposure poses detrimental health risks to humans [6,7]. Chronic exposure to arsenic has been reported to cause damage to neurological, reproductive, central nervous, renal, immune and liver systems as well as skin, bladder, and lung cancer in humans $[8,9]$. Rice is a widely cultivated agricultural crop that is one of the common staple foods in many parts of the world. Rice and ricebased products (cereal, bars, flour, and formula) are produced and sold world-wide annually. Rice plant is known to uptake and sequester arsenic in the grains more than any other part of the plant. Thus, consumption of rice and rice-based products become major sources of arsenic exposure to humans [10]. The potential for arsenic uptake and propagation into food-chain by rice poses great health risks.

\section{Materials and Methods}

\section{Sampling}

Triplicate samples of rice, soil, and water from previous plantharvest season were collected.

\section{Grid preparation}

Three $4 \mathrm{ft}$ by $4 \mathrm{ft}$ grids were carved out from the rest of the rice farm.

a) Grid 1 Soil was untreated and no soil amendment was added. It was used as the control which represents the nonexperimental portions of the rice farm.

b) Grid 2 soil was amended or treated with uncharred rice hulls from previous harvest.

c) Grid 3 soil was amended or treated with charred rice hulls from previous year rice harvest.

\section{Preparation of soil amendment}

Rice hulls from previous year harvest were divided into two. One half was charred in the field and the other was left uncharred.

\section{Rice planting and harvest, and analysis}

The same cultivar of rice was planted in the treated and untreated grids. For comparison, another cultivar of rice, Jasmine was planted in the other untreated control grid. All the grids were irrigated with water from the same source with undetectable arsenic level (below instrument detection limit of $20 \mu / \mathrm{L}$ ). The rice were harvested as usual and triplicate samples of the soil, rice, 
and stalk were collected, dried, and prepared for analysis using EPA Method 6010 (inductively Coupled Plasma-Atomic Emission Spectrometry (ICP-AES).

\section{Results and Discussions}

Figure 1 shows the average arsenic levels found in the soil, rice stalk, and rice grain for each of the grids. The levels of arsenic in each type of sample from each grid are as follows: Untreated control Grid 1, $1.9 \mathrm{mg} / \mathrm{kg}$ for soil, $5.5 \mathrm{mg} / \mathrm{kg}$ for stalk, and $4.3 \mathrm{mg} /$ $\mathrm{kg}$ for grain; Grid 2 treated with uncharred rice hull has arsenic at $1.8 \mathrm{mg} / \mathrm{kg}$ for soil, $6.6 \mathrm{mg} / \mathrm{kg}$ for stalk, and $3.6 \mathrm{mg} / \mathrm{kg}$ for grain. The Jasmine cultivar planted in the other untreated part of the rice farm has grain arsenic level of $3.5 \mathrm{mg} / \mathrm{kg}$. Grid 3 treated with charred rice hull has arsenic at $1.6 \mathrm{mg} / \mathrm{kg}$ for soil, $5.1 \mathrm{mg} / \mathrm{kg}$ for stalk, and $2.5 \mathrm{mg} /$ $\mathrm{kg}$ for grain These results suggest that treatment with charred rice hull reduced the level of arsenic in the rice grain.

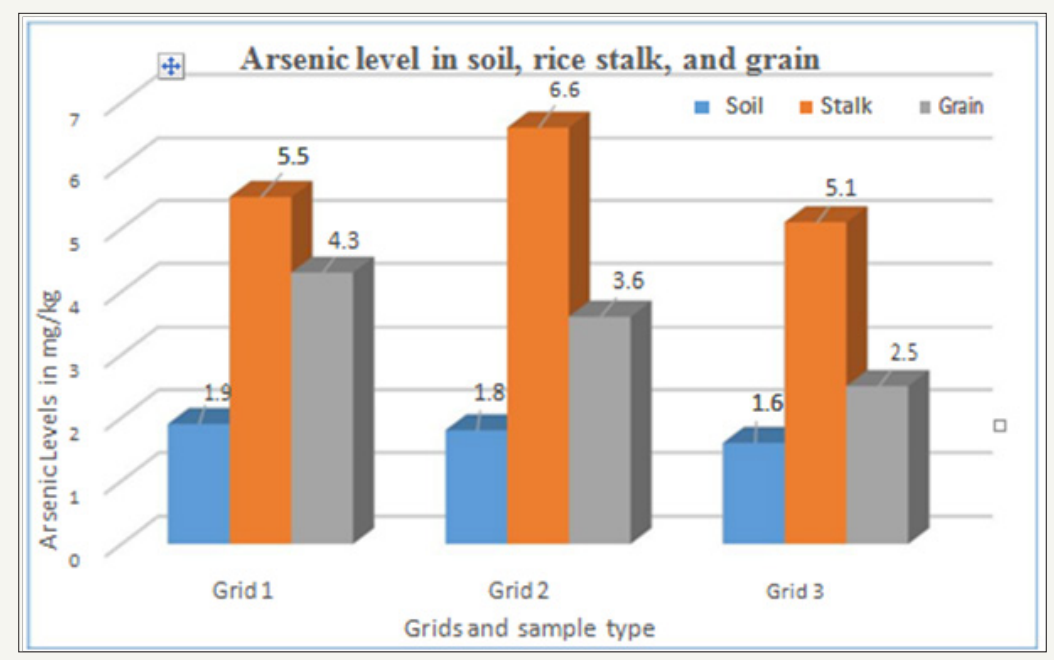

Figure 1: Arsenic levels in soil, rice stalk and rice grain.

\section{Conclusion}

The results clearly demonstrate that charred rice haul was able to reduce the uptake of arsenic from soil. It is worthy to note that the exposable limit for arsenic in soil set by US EPA Region VI is $0.36 \mathrm{mg} / \mathrm{kg}$ and about $100 \mathrm{ppb}$ in rice product. The level of arsenic found in the rice grain from treated grids is 25 and 36 times higher than allowable level in rice-product. Both EPA and FDA provide no clear guideline on the permissible level of arsenic in rice grain but recommend that consumers should eat a variety of grains to lower the risk of arsenic from rice consumption. The results further show that rice plant can uptake, transport, and accumulate arsenic from contaminated soil. Level of this update is dependent on cultivar type as demonstrated by the Jasmine and our experimental rice cultivers.

\section{References}

1. Garelick H, Jones H, Dybowska A, Valsami-Jones E (2008) Arsenic pollution sources. Rev Environ Contam Toxicol 197: 17-60.

2. Cynthia AC, Joseph AA, Marion O, Geoff V (2014) Leaching of chromium, copper, and arsenic from CCA-treated utility poles. Applied and Environmental Soil Science 2014: 11.
3. Lebow S, Foster D, Evans J (2004) Long-term soil accumulation of chromium, copper and arsenic adjacent to preservative-treated wood. Bull Environ Contam Toxicol 72(2): 225-232.

4. Mirlean N, Roisenberg A (2006) Effect of emissions of fertilizer production on the environment contamination by cadmium and arsenic in southern Brazil; Environmental Pollution 143(2): 335-340.

5. Atafar Z, Mesdaghinia A, Nouri J, Homaee M, Yunesian M, et al. (2010) Effect of fertilizer application on soil heavy metal concentration. Environ Monit \& Assess 160(1-4): 83-89.

6. Eisler R (2004) Arsenic hazards to humans, plants, and animals from gold mining. Rev Environ Contam Toxicol 180: 133-165.

7. Brammer H (2008) Threat of arsenic to agriculture in India, Bangladesh and Nepal. Economic and Political Weekly 43(47): 79-84.

8. Rahman M, Tondel M, Chowdhury IA, Axelson O (1999) Relations between exposure to arsenic, skin lesions and glucosuria. Occup Environ Med 56(4): 277-281.

9. Oberoi S, Barchowsky A, Wu F (2014) The global burden of disease for skin, lung, and bladder cancer caused by arsenic in food. Cancer Epidemiol Biomarkers Prev 23(7): 1187-1194.

10. Sohn E (2014) Contamination: the toxic side of rice. Nature 514: 62-63. 

International License

For possible submissions Click Here

Envilrommental Analysis \& Ecology Studies
Benefits of Publishing with us
- High-level peer review and editorial services
- Freely accessible online immediately upon publication
- Authors retain the copyright to their work
- Licensing it under a Creative Commons license

